\title{
Desempenho e análise econômica de novilhos Nelore submetidos a diferentes estratégias de suplementação alimentar nas fases de recria e engorda
}

\author{
[Performance and economic analysis of Nelore submitted to different strategies for \\ supplementary feeding during rearing and fattening] \\ F.L. Bicalho' ${ }^{1}$, F.A. Barbosa², D.S. Graça' ${ }^{2}$, S.L.S. Cabral Filho ${ }^{3}$, J.M. Leão ${ }^{1}$, C.F. Lobo ${ }^{3}$
${ }^{1}$ Aluno de pós-graduação - Escola de Veterinária - Universidade Federal de Minas Gerais - Belo Horizonte, MG ${ }^{2}$ Escola de Veterinária - Universidade Federal de Minas Gerais - Belo Horizonte, MG ${ }^{3}$ Faculdade de Agronomia e Medicina Veterinária - UnB - Brasília, DF

\begin{abstract}
RESUMO
Avaliou-se o desempenho produtivo e a eficiência econômica de diferentes estratégias de suplementação alimentar na fase de recria e engorda de novilhos Nelore. O experimento foi dividido em três períodos, seca, água e terminação. Cinquenta e quatro bezerros com peso médio inicial de $169,6 \mathrm{~kg}$ foram divididos em oito tratamentos, sendo cada tratamento uma estratégia de suplementação alimentar. No período da seca, os animais receberam suplemento proteico-energético-mineral com ingestão média diária de $0,1 \%$ do peso vivo médio (PV) para os tratamentos A, B, C, D, e 0,2\% do PV para os tratamentos E, F, G e H. No período das águas, os novilhos dos tratamentos $\mathrm{A}, \mathrm{B}, \mathrm{E}$ e $\mathrm{F}$ receberam suplemento proteicoenergético-mineral com ingestão média diária de $0,5 \%$ do $\mathrm{PV}$, e os novilhos dos tratamentos $\mathrm{C}, \mathrm{D}, \mathrm{G}$ e $\mathrm{H}$ receberam suplementação mineral. No período de terminação, os animais dos tratamentos B, D, F e H receberam suplemento proteico-energético-mineral com ingestão média diária de 1,4\% do PV, e os animais dos tratamentos A, C, E e G foram engordados em confinamento. Houve diferença estatística $(\mathrm{p}<0,05)$ para o peso final acumulado (PF). Os maiores valores de PF foram de 492,0; 475,1 e 473,1 kg para os animais dos tratamentos $\mathrm{F}, \mathrm{B}$ e $\mathrm{H}$, respectivamente. Os animais dos tratamentos que receberam suplemento $1,4 \%$ do PV na terminação permaneceram 70 dias a mais do que os animais que foram engordados em confinamento. Todas os tratamentos foram economicamente viáveis, contudo o tratamento $G$ apresentou o maior resultado de caixa, VPL e TIR, sendo eles $R \$ 349,00$; $R \$ 252,10$ e $2,45 \%$, respectivamente. A suplementação de proteína, energia e minerais a pasto ou em confinamento reduziu a idade ao abate dos animais e constitui uma alternativa economicamente viável para produção de bovinos de corte.
\end{abstract}

Palavras-chave: bovino de corte, confinamento, pasto, rentabilidade

\begin{abstract}
The aim of this study was to evaluate the production performance and economic efficiency of different strategies of supplementation on the rearing and fattening of Nelore calves. The experiment was divided in to three periods, Drought, Rainy and Finishing. Fifty four calves with average initial weight of 169.6 $\mathrm{kg}$ were divided in eight treatments, each treatment with one supplementation strategy. During the dry season the animals were protein-energy and mineral supplemented with an average daily intake of $0.1 \%$ of body weight $(B W)$ for strategies $A, B, C, D$ and $0.2 \%$ of $B W$ for strategies $E, F, G$ and $H$. During the rainy season, animals from strategies $A, B, E$ and $F$ were protein-energy and mineral supplemented with an average daily intake of $0.5 \%$ of $B W$ and strategies $C, D, G$ and $H$ received only mineral supplementation. During the finishing period, animals from strategies $B, D, F$ and $H$ were protein-energy and mineral supplemented with an average daily intake of $1.4 \%$ of $B W$ and animals from strategies $A, C$, $E$ and $G$ were fattened in feedlots. There was statistical difference $(p<0.05)$ for the cumulative final weight $(F W)$. Higher values of $F W$ were $492.0,475.1$ and $473.1 \mathrm{~kg}$ for animals from strategies $F, B$ and $H$
\end{abstract}

Recebido em 30 de outubro de 2012

Aceito em 14 de dezembro de 2013

E-mail: filipelagebicalho@yahool.com.br 
respectively. Animals from strategies supplemented $1.4 \%$ of $B W$ remained 70 days more in the termination period than animals fattened in feedlots. All strategies were economically viable, however, strategy $G$ had a major cash result, net present value (NPV) and internal rate of return (IRR), $R \$ 349.00$; $R \$ 252.10$ and $2.45 \%$ respectively. Protein, energy and mineral supplementation on pasture or feedlot reduces the age at slaughter of animals and is an economically viable alternative for production of beef cattle.

Keywords: beef cattle, feedlot, pasture, profitability

\section{INTRODUÇÃO}

$\mathrm{Na}$ produção de gado de corte, é importante eliminar as fases negativas de desenvolvimento dos animais, proporcionando condições de pleno desenvolvimento durante todo o ano, para que os animais possam alcançar condições de abate mais precocemente. A suplementação alimentar surge, neste contexto, como alternativa tecnológica efetiva e relevante para acelerar o ganho de peso animal e potencializar a utilização dos recursos forrageiros disponíveis (Euclides et al., 2009).

A suplementação de bovinos permite corrigir dietas desequilibradas, aumentar a eficiência de conversão das pastagens, melhorar o ganho de peso dos animais, encurtar os ciclos reprodutivos, de crescimento e engorda dos bovinos e aumentar a capacidade de suporte das pastagens. Resultados de pesquisa têm demonstrado o efeito positivo no incremento do ganho médio diário de peso vivo para bovinos em pastagens que receberam suplementação alimentar na época da seca (Baroni et al., 2010a) e na época das águas (Porto et al., 2009). Bovinos que consumiram pastagens tropicais com uso de suplementos múltiplos apresentaram ganhos de peso adicionais de 0,2 a $0,3 \mathrm{~kg} /$ bovino/dia, em comparação ao suplemento mineral na época das águas e da transição águaseca (Barbosa et al., 2007).

Essas estratégias alimentares com uso de suplemento múltiplo avaliam uma fase de vida do bovino, recria ou engorda, sem levar em consideração todo o período da desmama até o abate. Durante essas fases de recria e engorda, o ganho de peso pode ser influenciado por ganhos compensatórios que esses animais podem apresentar após período de restrição alimentar. Esse ganho compensatório pode reduzir ou até mesmo eliminar os benefícios da suplementação alimentar (Wadsworth, 1985).
Para que a estratégia de suplementação alimentar seja adotada, além do desempenho técnico, torna-se necessário que ela seja economicamente viável. O ganho em peso do animal tem que pagar o desembolso financeiro com a suplementação e os outros custos de produção (Barbosa et al., 2008). Trabalhos de pesquisas avaliando técnica e economicamente as diferentes estratégias alimentares para bovinos de corte da desmama ao abate são escassos e antigos (Euclides et al., 1998; Euclides et al., 2001), e não abordam o uso de suplementos múltiplos na época das águas. Diante do exposto, o objetivo deste trabalho foi avaliar o desempenho produtivo e a eficiência econômica de diferentes estratégias de suplementação alimentar na fase de recria e engorda de novilhos Nelore.

\section{MATERIAL E MÉTODOS}

O experimento foi conduzido na Fazenda Água Limpa, pertencente à Fundação Universidade de Brasília, no período de junho de 2009 a janeiro de 2011. A fazenda está localizada no Distrito Federal, cujas coordenadas geográficas são: $15^{\circ} 55^{\prime} 12.55^{\prime}$ "latitude sul e $47^{\circ} 55^{\prime} 12.55^{\prime}$ ' longitude oeste. A altitude é de aproximadamente 1.000 metros e o clima é do tipo tropical, com precipitações médias anuais em torno de $1500 \mathrm{~mm}$. A estação seca foi de junho a novembro do ano de 2009 , e a estação chuvosa foi de novembro de 2009 a julho de 2010.

A área experimental era composta de 12 piquetes de dois hectares cada, estabelecidos com Brachiaria brizantha cv. Marandu e providos de saleiros, bebedouros e cochos para suplementação concentrada, bem como de dois currais de confinamento, providos de cochos para suplementação volumosa e concentrada, saleiros e bebedouros. Foram utilizados dois boxes de confinamento $\left(20 \mathrm{~m}^{2} /\right.$ animal $)$, cocho de concreto coberto para fornecimento de alimentos 
e bebedouro com água à vontade regulada por boia automática.

O período experimental teve duração máxima de 591 dias e foi dividido em três períodos: seca, água e terminação, com 140, 266 e 185 dias cada, respectivamente. Na fase de terminação, os animais que foram engordados no confinamento permaneceram 110 dias, e os animais terminados em semiconfinamento ficaram 185 dias. Foram utilizados 54 bezerros desmamados da raça Nelore, entre sete e oito meses de idade, e peso vivo médio inicial de $169,6 \mathrm{~kg}$, os quais foram distribuídos aleatoriamente nos seguintes tratamentos:

Tratamento A - os animais receberam suplemento proteico-energético-mineral com ingestão média diária de $0,1 \%$ do peso vivo no primeiro período de seca; suplemento proteicoenergético-mineral com ingestão média diária de $0,5 \%$ do peso vivo no primeiro período das águas, e na terminação os animais foram confinados;

Tratamento B - os animais receberam suplemento proteico-energético-mineral com ingestão média diária de $0,1 \%$ do peso vivo no primeiro período de seca; suplemento proteicoenergético-mineral com ingestão média diária de $0,5 \%$ do peso vivo no primeiro período das águas, e na terminação os animais receberam suplemento proteico-energético-mineral com ingestão média diária de $1,4 \%$ do peso vivo (semiconfinamento);

Tratamento C - os animais receberam suplemento proteico-energético-mineral com ingestão média diária de $0,1 \%$ do peso vivo no primeiro período de seca; suplemento mineral no primeiro período das águas, e na terminação os animais foram confinados;

Tratamento D - os animais receberam suplemento proteico-energético-mineral com ingestão média diária de $0,1 \%$ do peso vivo no primeiro período da seca; suplemento mineral no primeiro período das águas, e na terminação os animais receberam suplemento proteicoenergético-mineral com ingestão média diária de $1,4 \%$ do peso vivo (semiconfinamento);

Tratamento E - os animais receberam suplemento proteico-energético-mineral com ingestão média diária de $0,2 \%$ do peso vivo no primeiro período de seca; suplemento proteicoenergético-mineral com ingestão média diária de $0,5 \%$ do peso vivo no primeiro período águas, e na terminação os animais foram confinados;

Tratamento F - os animais receberam suplemento proteico-energético-mineral com ingestão média diária de $0,2 \%$ do peso vivo no primeiro período de seca; suplemento proteicoenergético-mineral com ingestão média diária de $0,5 \%$ do peso vivo no primeiro período das águas, e na terminação os animais receberam suplemento proteico-energético-mineral com ingestão média diária de $1,4 \%$ do peso vivo (semiconfinamento);

Tratamento G - os animais receberam suplemento proteico-energético-mineral com ingestão média diária de $0,2 \%$ do peso vivo no primeiro período de seca; suplemento mineral no primeira período das águas, e na terminação os animais foram confinados;

Tratamento $\mathrm{H}-$ os animais receberam suplemento proteico-energético-mineral com ingestão média diária de $0,2 \%$ do peso vivo no primeiro período de seca; suplemento mineral no primeiro período das águas, e na terminação os animais receberam suplemento proteicoenergético-mineral com ingestão média diária de $1,4 \%$ do peso vivo (semiconfinamento).

O delineamento experimental utilizado foi $\mathrm{o}$ inteiramente ao acaso, com oito tratamentos e três a 10 repetições, e as médias de tratamentos foram comparadas por meio do teste de Tukey a $5 \%$ de significância, com o peso inicial dos animais como covariável. O modelo matemático foi o seguinte: $Y_{i j}=\mu+T_{j}+P I_{\mathrm{j}}+e_{i j}$, em que: $\mathrm{Y}_{\mathrm{ij}}$ $=$ ganho em peso e peso final do animal $\mathrm{j}$ pertencente ao tratamento $\mathrm{i} ; \mu=$ efeito médio; $\mathrm{T}_{\mathrm{i}}$ $=$ efeito fixo do tratamento $\mathrm{i} ; \mathrm{PI}_{\mathrm{j}}=$ covariável peso inicial do animal $\mathrm{j} ; \mathrm{e}_{\mathrm{ij}}=$ erro aleatório associado ao tratamento $\mathrm{i}$ a cada animal $\mathrm{j}$.

No início e durante o período experimental, os animais foram vermifugados e receberam vacinações preventivas. Foi adotado o sistema de pastejo contínuo, porém, a cada 14 dias, os animais de cada tratamento foram rotacionados nos piquetes como forma de eliminar os efeitos de piquete. A taxa de lotação média na primeira seca foi de 0,9 unidade animal (UA) de 450kg 
por hectare (ha), na primeira época das águas foi de 1,3UA/ha, e na terminação dos animais em semiconfinamento a taxa média foi de 2,0 $\mathrm{UA} / \mathrm{ha}$. As pesagens dos animais foram realizadas a cada 28 dias, após jejum alimentar de 24 horas e jejum hídrico de 16 horas.

Os suplementos foram oferecidos no cocho três vezes por semana. A composição dos suplementos e os valores nutricionais se encontram na Tab. 1. No período da terminação, os animais passaram por um período de adaptação as dietas experimentais de aproximadamente 21 dias. No confinamento, as dietas eram fornecidas três vezes ao dia $(7 \mathrm{~h} 30$, $10 h 30$ e 15h30).

Tabela 1. Proporção dos ingredientes e composição químico-bromatológica do suplemento mineral (SM), suplemento proteico-energético-mineral com 0,1\% PV; 0,2\% PV; 0,5\% PV; $1,4 \%$ PV e da dieta de confinamento (Conf)

\begin{tabular}{ccccccc}
\hline \multirow{2}{*}{ Ingredientes } & \multicolumn{7}{c}{ Suplementos e dieta do confinamento } \\
\cline { 2 - 7 } & SM & $0,1 \%$ PV & $0,2 \%$ PV & $0,5 \%$ PV & $1,4 \%$ PV & Conf \\
\hline Silagem de milho (\%) & - & - & - & - & - & 30,00 \\
Milho moído (\%) & - & 47,74 & 0,65 & - & 43,50 & 43,27 \\
Casca de soja (\%) & - & - & - & 90,66 & 10,50 & 13,18 \\
Farelo de girassol (\%) & - & - & - & - & - & 10,80 \\
Farelo de soja & - & - & 51,78 & - & - & - \\
Caulim & - & 11,50 & 16,27 & - & - & - \\
Ureia (\%) & - & 13,45 & 5,00 & 2,67 & - & 1,05 \\
Suplemento mineral - \% & 45,00 & 15,00 & 15,00 & 2,86 & - & - \\
Sal branco - \% & 55,00 & 10,76 & 10,75 & 2,86 & - & - \\
Calcário (\%) & - & - & - & - & - & 0,70 \\
Sulfato de amônio - \% & - & 1,55 & 0,55 & 0,95 & - & - \\
Núcleo proteico-mineral & - & - & - & - & 46,00 & - \\
Núcleo confinamento (\%) & - & - & - & - & - & 1,00 \\
\hline Composição nutricional & - & - & & & \\
\hline MS (\%) & - & 92,51 & 92,75 & 85,53 & 88,20 & 57,21 \\
PB (\%) & - & 45,23 & 42,11 & 20,83 & 18,50 & 13,90 \\
NDT* (\%) & - & - & - & 75,74 & 79,10 & 75,30 \\
\hline
\end{tabular}

* NDT $=0,99 \times$ DIVMO (Nutrient..., 1996).

Os consumos do suplemento proteico-energéticomineral e do suplemento mineral foram calculados pela soma das quantidades de suplemento fornecidas, diminuído da sobra e dividido pelo número de cabeças e pelo número de dias. No confinamento, foi feita a mensuração do consumo médio da dieta de cada tratamento, por meio da quantidade de alimento fornecida, que foi ajustada diariamente, com base no consumo observado no dia anterior, e as sobras foram pesadas diariamente.

Foi feita avaliação da disponibilidade de matéria seca dos piquetes no primeiro dia de cada período experimental por meio do corte, a $5 \mathrm{~cm}$ do solo, de oito amostras, compreendidas em um retângulo metálico de 0,5 x $1,0 \mathrm{~m}$, alocado aleatoriamente de acordo com metodologia proposta por McMeniman (1997). Dessa amostra total foram retiradas duas subamostras representativas, amostra verde e amostra composta. A subamostra composta teve como objetivo avaliar o percentual das frações da matéria seca verde (MSV) e da matéria seca morta (MSM), dessa forma, foi feita a separação manual dos constituintes morfológicos (lâmina verde, lâmina seca, haste e matéria morta). A MSV foi obtida com base na soma das frações de lâmina verde e haste, e a MSM com base na fração de lâmina seca e matéria morta.

As amostras de forragem, dos alimentos que compõem as dietas experimentais e as sobras do confinamento foram analisadas nas metodologias citadas por Silva e Queiroz (2002), quanto ao teor de matéria seca (MS), proteína bruta (PB), fibra em detergente neutro (FDN) e fibra em detergente ácido (FDA). As porcentagens dos nutrientes digestíveis totais (NDT) foram estimadas pela equação, proposta por Capelle 
(2001), em que: NDT $=83,79-0,4171$ FDN para forragem e NDT $=0,99$ X DIVMO (Nutrient..., 1996) para os suplementos proteico-energético e minerais.

Foram utilizadas planilhas eletrônicas do Programa Excel® para estimar os indicadores econômicos. Consideraram-se como despesas: valor de compra dos animais, valor de arrendamento das pastagens, suplementos minerais e proteico-energéticos, ração concentrada e volumoso do confinamento, medicamentos e mão de obra para fornecimento das dietas.

O valor médio dos bezerros desmamados foi de $\mathrm{R} \$ 424,38 /$ cabeça, o valor do arrendamento da pastagem foi de $\mathrm{R} \$ 15,00 /$ cabeça/mês, o custo por aplicação dos medicamentos foi de $\mathrm{R} \$ 4,00 /$ cabeça/aplicação. Os custos dos suplementos foram de $\mathrm{R} \$ 0,77 / \mathrm{kg}$ para o suplemento com IMS de $0,1 \%$ do PV; R $\$ 0,76 / \mathrm{kg}$ para o suplemento com IMS de 0,2\% do PV; $\mathrm{R} \$ 0,39 / \mathrm{kg}$ para o suplemento de $0,5 \%$ do PV e $\mathrm{R} \$ 0,36 / \mathrm{kg}$ para o suplemento com IMS de $1,4 \%$ do PV. O custo do suplemento mineral foi de $\mathrm{R} \$ 1,17 / \mathrm{kg}$, e o custo da dieta do confinamento foi de $\mathrm{R} \$ 3,50 /$ bovino/dia.

Foram considerados os valores reais praticados em 2009 para compra de insumos e os valores reais referentes à venda dos animais de 2010 e 2011. Para estimativa do custo com mão de obra, foi considerado salário rural referente aos anos de 2009 a 2011com encargos sociais, em 4,0 horas/homem/dia para todos os tratamentos correspondentes ao tempo para fornecimento da alimentação.

Considerou-se o valor de arroba de boi gordo no dia do abate, sendo o valor de venda dos animais de $\mathrm{R} \$ 3,66 / \mathrm{kg}$ para os animais engordados em confinamento e de $\mathrm{R} \$ 3,33 / \mathrm{kg}$ para os animais engordados em semiconfinamento. Para a análise econômica, foi calculado o resultado de caixa, sendo o resultado da receita subtraído da despesa do fluxo de caixa, do valor presente líquido (VPL) e da taxa interna de retorno (TIR). Para o cálculo do VPL, foi considerada uma taxa de juros de $0,56 \%$ ao mês.

\section{RESULTADO E DISCUSSÃO}

Os valores médios da disponibilidade de Brachiaria brizantha cv. Marandu de matéria seca total (MST) para os períodos da primeira seca, da primeira água e da terminação foram de 4720,4772 e $5855 \mathrm{~kg} / \mathrm{ha}$, respectivamente, e para matéria seca verde (MSV) foram de 612, 994 e $861 \mathrm{~kg} / \mathrm{ha}$. A disponibilidade de MST da forragem não foi limitante para o desempenho dos animais, apresentando valores acima de $2.000 \mathrm{~kg}$ de MST/ha, de acordo com Flores et al. (2008). Já os valores de MSV foram abaixo dos $1.000 \mathrm{~kg} / \mathrm{ha}$ recomendados por Euclides et al. (2000).

Os dados da composição nutricional média das amostras da forragem são mostrados na Tab. 2. Ocorreram variações nos valores nutricionais da forragem com as diferentes épocas do ano.

Tabela 2. Composição químico-bromatológica dos componentes da Brachiaria brizantha cv.Marandu ao longo do período experimental

\begin{tabular}{cccc}
\hline & Seca & Água & Terminação \\
\hline MS (\%) & 42,84 & 40,85 & 47,70 \\
PB (\%MS) & 4,35 & 6,49 & 5,65 \\
FDN (\%MS) & 70,64 & 77,31 & 74,13 \\
FDA (\%MS) & 39,2 & 43,6 & 42,27 \\
MM (\%MS) & 6,64 & 7,38 & 7,25 \\
NDT (\%)* & 50,67 & 51,55 & 52,86 \\
\hline
\end{tabular}

MS = matéria seca, $\mathrm{PB}=$ proteína bruta, FDN $=$ fibra em detergente neutro, FDA = fibra em detergente ácido, $\mathrm{MM}=$ matéria mineral, NDT $=$ nutrientes digestíveis totais. ${ }^{*}$ NDT $=83,79-0,4171$ FDN (Capelle et al., 2001).

Os valores de peso final acumulado (PF), ganho médio diário acumulado (GMD) e idade ao abate são apresentados na Tab. 3. Foram observadas diferenças $(p<0,05)$ entre os tratamentos para o peso final acumulado, sendo os maiores valores de $\mathrm{PF}$ para os tratamentos $\mathrm{F}, \mathrm{B}$ e $\mathrm{H}$ em relação ao C. $\mathrm{O}$ menor $\mathrm{PF}$ acumulado do tratamento $\mathrm{C}$ $(\mathrm{p}<0,05)$ está relacionado à menor quantidade ingerida de nutrientes com a suplementação na primeira seca, com ingestão de $0,1 \%$ (do peso 
vivo), apenas suplementação mineral nas águas e, posteriormente, com os animais sendo engordados em confinamento, constituindo este tratamento o de menor nível de suplementação alimentar durante o período de pastejo. Durante o confinamento, esses animais não conseguiram atingir o mesmo peso final dos outros tratamentos.
Os animais pertencentes aos tratamentos $\mathrm{F}, \mathrm{B}$ e $\mathrm{H}$, com maior $\mathrm{PF}(\mathrm{p}<0,05)$, em relação ao $\mathrm{C}$, foram bovinos que receberam suplementação proteico-energético-mineral de $1,4 \%$ do peso vivo em semiconfinamento, os quais foram abatidos aos 27 meses de idade, permanecendo, assim, 70 dias a mais no experimento.

Tabela 3. Desempenho de novilhos Nelore nas fases de recria e engorda para peso inicial (PI), peso final (PF), ganho médio diário (GMD) e idade ao abate nos diferentes tratamentos

\begin{tabular}{ccccc}
\hline Tratamentos & PI $(\mathrm{kg})$ & PF $(\mathrm{kg})$ & GMD $(\mathrm{kg})$ & Idade ao abate (dias) \\
\hline A & 170,0 & $457,3 \mathrm{ab}$ & $0,511 \mathrm{a}$ & 746 \\
B & 170,0 & $475,1 \mathrm{a}$ & $0,515 \mathrm{a}$ & 816 \\
C & 169,0 & $418,8 \mathrm{~b}$ & $0,479 \mathrm{a}$ & 746 \\
D & 168,0 & $461,0 \mathrm{ab}$ & $0,495 \mathrm{a}$ & 716 \\
E & 166,0 & $442,5 \mathrm{ab}$ & $0,529 \mathrm{a}$ & 816 \\
F & 169,0 & $492,0 \mathrm{a}$ & $0,546 \mathrm{a}$ & 746 \\
G & 170,0 & $447,2 \mathrm{ab}$ & $0,532 \mathrm{a}$ & 816 \\
H & 176,0 & $473,1 \mathrm{a}$ & $0,502 \mathrm{a}$ & \\
\hline
\end{tabular}

Médias seguidas de letras distintas, na mesma coluna, diferem entre si estatisticamente $(\mathrm{p}<0,05)$.

A redução da idade ao abate em 70 dias dos animais confinados relaciona-se com o maior GMD desses animais durante o período de confinamento e ao acabamento de carcaça comparado ao mesmo período de tempo com os animais que estiveram no semiconfinamento. Apesar de os animais do confinamento terem sido abatidos mais leves, devido à ingestão de uma dieta rica em energia, estes animais apresentaram um padrão de acabamento aceitável para o abate. Já os animais do semiconfinamento tiveram que ficar por período maior para que pudessem ganhar mais peso e atingir um padrão de acabamento aceitável para o abate.

Estes resultados são semelhantes aos encontrados por Euclides et al. (1998), em que os animais que receberam suplementação proteico-energéticomineral na primeira seca e foram confinados na segunda seca, tiveram a idade ao abate reduzida em 120 dias quando comparados aos animais que receberam suplementação proteico-energéticomineral na primeira e segunda secas.

Os valores para idade ao abate encontrados neste estudo são inferiores aos encontrados por Euclides et al. (1998), em que os animais receberam apenas suplementação mineral nas fases de recria e engorda, quando foram abatidos com 33 e 40 meses de idade. Baroni et al. (2010a) trabalharam com novilhos Nelore na fase de engorda sob pastagens, aos quais foi fornecida suplementação proteico-energético-mineral com $25 \%$ de PB com consumo de $0,9 \%$ do PV, e os animais apresentaram um PF de 458,6kg aos 33 meses de idade.

Não houve diferença $(\mathrm{p}>0,05)$ para o ganho médio diário acumulado (GMD). Os resultados de GMD para os tratamentos em que os animais foram semiconfinados são semelhantes aos encontrados por Euclides et al. (1998), em que os animais que receberam suplementação alimentar durante a primeira e a segunda seca tiveram um GMD acumulado de 510g, ganho este semelhante aos encontrados no presente estudo, que variaram de 495 a $546 \mathrm{~g}$.

Resultados encontrados neste experimento foram superiores aos obtidos por Baião et al. (2004) com bovinos mestiços Nelore no período seco do ano, no qual os autores verificaram ganhos de peso de 0,18 e $0,46 \mathrm{~kg} / \mathrm{animal} /$ dia para consumos de 1,1 e 2,8kg/animal.dia de suplemento, respectivamente. Baroni et al. (2010b), ao trabalharem com novilhos Nelore castrados em pastagens no período da seca, encontraram resposta semelhante a este estudo, quando forneceram dietas com teor de $31,9 \%$ de PB e obtiveram ganhos de $0,588 \mathrm{~kg} / \mathrm{animal} /$ dia para um consumo de suplemento de $4 \mathrm{~kg} / \mathrm{animal} / \mathrm{dia}$. 
As despesas, a receita, o resultado de caixa, o valor presente líquido (VPL) e a taxa interna de retorno (TIR) estão apresentados para cada tratamento na Tab. 4. Os resultados econômicos foram positivos para todos os tratamentos avaliados, indicando que as diferentes estratégias alimentares foram viáveis, isto é, a receita obtida conseguiu remunerar as despesas operacionais.

O maior retorno econômico foi do tratamento $\mathrm{G}$, em que o VPL foi de R $\$ 252,10 /$ bovino e a TIR foi de $2,45 \%$ ao mês, sendo esses valores obtidos pelo maior resultado de caixa entre os tratamentos, que foi de $\mathrm{R} \$ 349,00$ por bovino. Os menores valores de VPL e TIR foram do tratamento $\mathrm{B}$, com valor de $\mathrm{R} \$ 92,00 /$ bovino e de $1,16 \%$ ao mês, respectivamente.

Os animais dos tratamentos que foram engordados em confinamento, A, C, E e G, atingiram um peso final para o abate aos 746 dias de idade, coincidindo com o período de valorização do preço de venda do boi gordo. Esses tratamentos obtiveram um acréscimo de $10 \%$ no preço de venda em comparação com os animais que foram engordados recebendo $1,4 \%$ do PV em semiconfinamento e abatidos aos 816 dias de idade em um período com menor preço do boi gordo. Além disso, deve ser levado em consideração que o animal suplementado sairá mais rápido da propriedade, o que reduz o custo de permanência e permite a entrada de nova categoria animal, com aumento de giro de capital.

Os valores deste estudo se assemelham aos encontrados por Euclides et al. (1998), os quais encontraram, entre cinco estratégias alimentares avaliadas, o segundo maior valor para o VPL na estratégia em que os animais receberam suplementação na primeira seca e foram confinados na segunda seca. Itavo et al. (2008), em experimento que avaliou diferentes suplementos proteico-energéticominerais, encontraram lucro de $\mathrm{R} \$ 0,65 / \mathrm{kg}$ para os animais que receberam suplemento à base de minerais+ureia+milho, quando comparado com um lucro de $\mathrm{R} \$ 0,60 / \mathrm{kg}$ para os animais que receberam apenas suplementação mineral.

Tabela 4. Médias das despesas ( $\mathrm{R} \$$ /bovino), da receita ( $\mathrm{R} \$ /$ bovino), do resultado de caixa ( $\mathrm{R} \$ /$ bovino), do valor presente líquido (VPL) (R\$) e da taxa interna de retorno (TIR) (\%) dos diferentes tratamentos

\begin{tabular}{|c|c|c|c|c|c|c|c|c|}
\hline \multirow{2}{*}{ Despesas (R\$/bovino) } & \multicolumn{8}{|c|}{ Tratamentos } \\
\hline & A & $\mathrm{B}$ & $\mathrm{C}$ & $\mathrm{D}$ & $\mathrm{E}$ & $\mathrm{F}$ & $\mathrm{G}$ & $\mathrm{H}$ \\
\hline Compra de animais & $\begin{array}{c}425,0 \\
0\end{array}$ & 425,00 & 422,50 & 420,00 & 415,00 & 422,50 & 425,00 & 440,00 \\
\hline Suplementação & $\begin{array}{c}612,5 \\
4\end{array}$ & 530,65 & 460,48 & 378,54 & 628,34 & 546,34 & 476,17 & 394,17 \\
\hline Mão de obra & $\begin{array}{c}103,4 \\
6\end{array}$ & 115,71 & 103,46 & 115,71 & 103,46 & 115,71 & 103,46 & 115,71 \\
\hline Medicamentos & 16,00 & 20,00 & 16,00 & 20,00 & 16,00 & 20,00 & 16,00 & 20,00 \\
\hline Arrendamento & $\begin{array}{c}210,0 \\
0\end{array}$ & 300,00 & 210,00 & 300,00 & 210,00 & 300,00 & 210,00 & 300,00 \\
\hline Subtotal (A) & $\begin{array}{c}1367 \\
00\end{array}$ & $\begin{array}{c}1391,3 \\
5 \\
\end{array}$ & $\begin{array}{c}1212,4 \\
4 \\
\end{array}$ & $\begin{array}{c}1234,2 \\
5 \\
\end{array}$ & $\begin{array}{c}1372,6 \\
9 \\
\end{array}$ & $\begin{array}{c}1404,5 \\
4 \\
\end{array}$ & $\begin{array}{c}1290,5 \\
4 \\
\end{array}$ & $\begin{array}{c}1269,9 \\
4 \\
\end{array}$ \\
\hline \multicolumn{9}{|l|}{ Receita (R \$/bovino) } \\
\hline $\begin{array}{c}\text { Venda de animal (B) } \\
\text { (R\$/bovino) }\end{array}$ & $\begin{array}{c}1676, \\
77 \\
\end{array}$ & $\begin{array}{c}1583,6 \\
7 \\
\end{array}$ & $\begin{array}{c}1535,4 \\
2 \\
\end{array}$ & $\begin{array}{c}1536,6 \\
7 \\
\end{array}$ & $\begin{array}{c}1622,5 \\
0 \\
\end{array}$ & $\begin{array}{c}1640,0 \\
0 \\
\end{array}$ & $\begin{array}{c}1639,5 \\
9 \\
\end{array}$ & $\begin{array}{c}1577,0 \\
7 \\
\end{array}$ \\
\hline $\begin{array}{c}\text { Resultado de caixa (B-A) } \\
(\mathrm{R} \$ / \text { bovino })\end{array}$ & $\begin{array}{c}309,7 \\
7 \\
\end{array}$ & 192,32 & 323,02 & 302,42 & 249,81 & 235,46 & 349,00 & 307,13 \\
\hline VPL (R\$) & $\begin{array}{c}212,0 \\
2\end{array}$ & 92,00 & 230,55 & 198,77 & 157,48 & 129,40 & 252,10 & 199,57 \\
\hline $\operatorname{TIR}(\%)$ & 2,09 & 1,16 & 2,36 & 1,91 & 1,72 & 1,37 & 2,45 & 1,96 \\
\hline
\end{tabular}

VPL - valor presente líquido; TIR - taxa interna de retorno ao mês. 
Ao avaliarem diferentes estratégias de suplementação nas fases de recria e terminação, Figueredo et al. (2007) encontraram uma TIR de $1,26 \%$ ao mês para bovinos abatidos aos 720 dias de idade em condições semelhantes a este estudo e um valor negativo para TIR, para a estratégia cujos animais foram abatidos aos 1200 dias de idade sem receber suplementação proteicoenergética.

Euclides et al. (2009) encontraram valores para margem líquida de $\mathrm{R} \$ 41,71$ a $\mathrm{R} \$ 248,36$ para bovinos que receberam 0,6 e $1,0 \%$ do PV de suplemento proteico-energético-mineral em pastagens de Brachiaria brizantha cv. Marandu, o que demonstra a viabilidade econômica da suplementação alimentar na fase de terminação de bovinos de corte.

\section{CONCLUSÃO}

As estratégias de suplementação proteicoenergético-mineral para bovinos, em pastagens tropicais, durante as fases de recria e engorda dos bovinos permitem abatê-los com idades menores que 28 meses.

A suplementação alimentar pode ser recomendada para recria e engorda de bovinos por apresentar viabilidade econômica com resultados positivos de VPL e TIR.

\section{REFERÊNCIAS}

BAIÃO, E.A.M.; BAIÃO, A.F.F.; ANDRADE, I.F. et al. Avaliação do desempenho de novilhos mestiço nelore recebendo níveis de suplementação a pasto, no período seco do ano. In: REUNIÃO ANUAL DA SOCIEDADE BRASILEIRA DE ZOOTECNIA, 41., 2004, Campo Grande. Anais... São Paulo: Sociedade Brasileira de Zootecnia, 2004. (CD-ROM).

BARBOSA, F.A.; GRAÇA, D.S.; MAFFEI, F.V. et al. Desempenho e consumo de matéria seca de bovinos sob suplementação proteico energética, durante a época de transição água-seca. Arq. Bras. Med. Vet. Zootec., v.59, p.160-167, 2007.

BARBOSA, F.A.; GRAÇA, D.S.; GUIMARÃES, P.H.S; SILVA JÚNIOR, F.V. Análise econômica da suplementação proteicoenergética de novilhos durante o período de transição entre água-seca. Arq. Bras. Med. Vet. Zootec., v.60, p.911-916, 2008.
BARONI, C.E.S; LANA, R.P.; MANCIO, A.B. et al. Níveis de suplemento à base de fubá de milho para novilhos Nelore terminados a pasto na seca: desempenho, características de carcaça e avaliação do pasto. Rev. Bras. Zootec., v.39, p.175-182, 2010a.

BARONI, C.E.S.; LANA, R.P.; MANCIO, A.B. et al. Desempenho de novilhos suplementados e terminados em pasto, na seca, e avaliação do pasto. Arq. Bras. Med. Vet. Zootec, v.62, p.373381, 2010b.

CAPELLE, E.R.; VALADARES FILHO, S.C.; SILVA, J.F.C. et al. Estimativas do valor energético a partir de características químicas e bromatológicas dos alimentos. Rev. Bras. Zootec., v.30, p.1837-1856, 2001.

EUCLIDES, V.P.B.; EUCLIDES FILHO, K.; ARRUDA, Z.J.; FIGUEREDO, G.R. Desempenho de novilhos em pastagens de Brachiaria decumbens submetidos a diferentes regimes alimentares. Rev. Bras. Zootec., v.27, p.246-254, 1998.

EUCLIDES, V.P.B.; CARDOSO, E.G.; MACEDO, M.C.M.; OLIVEIRA, P.O. Consumo voluntário de Brachiaria decumbens cv. Basilik e Brachiaria brizantha cv. Marandu sob pastejo. Rev. Bras. Zootec., v.29, p.2200-2208, 2000.

EUCLIDES, V.P.B.; EUCLIDES FILHO, K.; ARRUDA, Z.J.; FIGUEREDO, G.R. Desempenho de novilhos F1s Angus-Nelore em pastagens de Brachiaria decumbens submetidos a diferentes regimes alimentares. Rev. Bras. Zootec., v.30, p.470-481, 2001.

EUCLIDES, V.P.B.; RAFFI, A.S.; COSTA, F.P. et al. Valor nutritivo da forragem e produção animal em pastagens de Brachiaria brizantha. Pesq. Agrop. Bras., v.44, p.98-106, 2009.

FIGUEREDO, M.D.; OLIVEIRA, A.S.; SALES, M.F.L. et al. Análise econômica de quatro estratégias de suplementação para recria e engorda de bovinos em sistema pastosuplemento. Rev. Bras. Zootec., v.36, p.14431453, 2007.

FLORES, R.S.; EUCLIDES, V.P.B.; ABRÃO, M.P.C. et al. Desempenho animal, produção de forragem e características estruturais dos capins marandu e xaraés submetidos a intensidades de pastejo. Rev. Bras. Zootec., v.37, p.1355-1365, 2008. 
ÍTAVO, L.C.V.; TOLEMTINO, T.C.P.; ÍTAVO, C.C.B.F. et al. Consumo, desempenho e parâmetros econômicos de novilhos Nelore e F1 Brangus $\mathrm{x}$ Nelore terminados em pastagens, suplementados com mistura mineral e sal nitrogenado com ureia ou amireia. Arq. Bras. Med. Vet. Zootec., v.60, p.419-427, 2008.

McMENIMAN, N.P. Methods of estimating intake of grazing animals. In: SIMPÓSIO SOBRE TÓPICOS ESPECIAIS EM ZOOTECNIA, 1997, Juiz de Fora. Anais... Juiz de Fora: SBZ, 1997, p.133-168.

NUTRIENT requirements of beef cattle 7.ed. Washington: National Academy of Sciences, 1996. 242p.
PORTO, M.O.; PAULINO, M.F.; VALADARES FILHO, S.C. et al. Fontes suplementares de proteína para novilhos mestiços em recria em pastagens de capim-braquiária no período das águas: desempenho produtivo e econômico. Rev. Bras. Zootec., v.38, p.1553-1560, 2009.

SILVA, D.J.; QUEIROZ, A.C. Análises de alimentos (métodos químicos e biológicos). 3.ed. Viçosa, MG: Editora UFV, 2002. 235p.

WADSWORTH, J. A model to evaluate the economic merits of dry season feeding of growing/fattening cattle in the sub-humid tropics. Agric. Systems, v.16, p.85-107, 1985. 